\title{
Pre-Service Teachers Use E-learning Technologies to Enhance Their Learning
}

\author{
Judith J. Smith and H. Carol Greene \\ Department of Elementary Education \\ and Middle Grades Education, \\ East Carolina University, Greenville, NC, USA
}

\author{
smithjud@ecu.edu greeneh@ecu.edu
}

\section{Executive Summary}

The purpose of this study was twofold. The primary purpose was to improve pre-service teacher education by using technology to help pre-service teachers bridge the gap between academic preparation and practice. The secondary, but still important, objective was to familiarize preservice teachers in the use of technology to support their future pedagogical activities. Therefore, this research sought to develop a method for training undergraduate students in designing, implementing, and evaluating lesson plans to solidify the relationship between research, pedagogy, and teaching practice. Specifically, this study investigated the implementation of e-learning as a method of instruction to help pre-service teachers evaluate and improve upon the implementation of their lesson plans during their real world practicum experiences. The study was guided by the following research questions: 1) What successes, challenges, and benefits do university instructors and pre-service teachers experience in using and analyzing video in teacher education methods coursework? 2) In what ways did the use of e-learning help the pre-service teachers improve their teaching during the practicum experience? Results showed that participants reported improved lesson planning, improved lesson implementation, visual interpretations of best practices, modeling, and peer and university instructor feedback as successes of the e-learning project. Challenges included participants' frustrations of being overworked and overwhelmed with the technical problems associated with e-learning. Overall participants judged the e-learning project as a very positive aspect of their teacher training.

Keywords: e-learning, teacher education, $21^{\text {st }}$ century learners, teaching and learning

\section{Introduction}

One of the multiple realities of implementing quality preparation and support of teacher educators is inclusion of $21^{\text {st }}$ century "technology" skills in teaching. To prepare K-12 students for the future, we must ensure that our teachers are equipped for the future as well. Therefore, as teacher

Material published as part of this publication, either on-line or in print, is copyrighted by the Informing Science Institute. Permission to make digital or paper copy of part or all of these works for personal or classroom use is granted without fee provided that the copies are not made or distributed for profit or commercial advantage AND that copies 1) bear this notice in full and 2) give the full citation on the first page. It is permissible to abstract these works so long as credit is given. To copy in all other cases or to republish or to post on a server or to redistribute to lists requires specific permission and payment of a fee. Contact Publisher@InformingScience.org to request redistribution permission. educators, we are challenged to revise our teacher preparation programs to reflect the needs of $21^{\text {st }}$ century learners so that we produce teachers who effectively and comfortably use technology to enhance student learning. While today's college students may be very familiar with social networking sites, digital music, and video sharing, they are not as familiar with many of the opportunities technology offers to enhance 
and provide quality K-12 instruction in a classroom setting (Albion, 2008; Orey, McClendon \& Branch, 2006). Effective technology integration by instructors in the college classroom is also often lacking so that pre-service teachers are not seeing the use of technology in education modeled for them (Cuban, 2001; Dawson, 2006; Koehler \& Mishra, 2007; Swain, 2006).

In investigating the teaching of technology-assisted teaching, we have identified two challenges: first, the need to generally increase the technical competency of pre-service teachers, and second, the need to help them better understand how e-learning technologies can be effectively applied. Thus, we wanted to evaluate a means of familiarizing pre-service teachers with using e-learning technology while modeling the use of technology to achieve a set of pedagogical learning objectives. Since we did not have the resources to implement a dedicated "Teaching with Technology" course, we needed to identify a course within an existing curriculum where we saw an opportunity to have our students use e-learning technology to enhance their learning.

We elected to focus on the particularly challenging area of helping our students, i.e., pre-service teachers, integrate theory and methods from their university coursework into teaching practice (Duquette, 1993; Fang, 1996; McCormack, Gore, \& Thomas, 2006). Although teacher education programs strive to instill in teacher candidates the ability to transition the theory of pedagogy into practice as they deliberate their approaches to instruction, this remains an area of great difficulty for many pre-service teachers. Education researchers have found reflective practice may be an effective way to support pre-service teachers in connecting their university learning experiences to the practice of teaching students (Lai \& Calandra, 2010; Rhine \& Bryant, 2007; Snoeyink, 2010). Consequently, the objectives of our efforts need to be understood on two levels: 1) to model and to familiarize pre-service teachers with an example of effective use of technology in instruction, and 2) to assist our students to bridge the gap between academic preparation and teaching practice by examining their own teaching through video sharing and reflection. The study represents our evaluation of the initiative.

Specifically, this study evaluated the implementation of e-learning as a method of instruction to help pre-service teachers evaluate and improve upon the implementation of their lesson plans during their real world practicum experiences and assessed student perceptions regarding the use of technology in achieving the learning objectives.

Accordingly, the study was guided by the following research questions: 1) What successes, challenges, and benefits do university instructors and pre-service teachers experience in using and analyzing video in teacher education methods coursework? 2) How did the pre-service teachers perceive the usefulness of e-learning to help them improve their teaching during the practicum experience?

\section{Review of the Literature}

This review first discusses the need for technology integration in our K-12 classrooms and to what degree technology is being utilized and valued as an important part of K-12 students' educations. From there, this review explores how technology, specifically e-learning, may support the instruction of pre-service teachers in the college classroom.

\section{Limitations to Technology Integration in Today's Classrooms}

Educators agree that to prepare students for the $21^{\text {st }}$ century, our educational system requires broad and intensive use of technology; therefore, teachers must adjust their traditional modes of instruction to include these $21^{\text {st }}$ century skills. For example, teachers' use of the internet is necessary in order to connect children to the real world in an increasingly global learning environment (McCoog, 2008; Ross, 2000; Vockley, 2007). However, Moylan (2008) found that a significant 
gap exists between the knowledge and skills needed for success in life and the current primary and secondary education systems in place throughout the world.

The idea that schools are using technology widely is just not true. According to Vockley (2007), even with federal, state, and local investments in technology, most schools use technology frugally. She stated, "To a wireless nation, which relies on technology for ordinary tasks and extraordinary achievements, it is shocking and inconceivable....that technology is marginalized in the complex and vital affairs of education." This lack of technology integration is a problem for today's teachers as many researchers have noted the importance of utilizing technology in classrooms. McCoog (2008), Moersch (2011), and Walker, Redmond and Giles (2010), have all stated that technology needs to be part of the daily curriculum in elementary and secondary school, yet this is often not the case.

Since technology is embedded in all aspects of our daily lives, and its advances and uses in our society are constantly increasing, one must wonder why its use in education and public schools lags so far behind. Several studies have attempted to address this issue. For example, in a qualitative study, Bauer and Kenton (2005) reported that the 30 teachers they interviewed were reluctant to integrate technology into their classrooms because of problems with, or lack of, equipment; scheduling difficulties; and software availability. Additionally, Hsu (2010) and Swain (2006) concluded that teachers in their studies felt that technology integration was not a valuable use of time and effort, while other teachers felt technology was arduous to use (Hofer \& Swan, 2006).

Other studies have found that even with inclusion of new technologies in the classroom, actual instructional strategies remain largely unchanged or that these attempts are sometimes met with a degree of disdain. Hofer and Swan (2006) found that teachers are hesitant to adopt a transformative view of technology where laptops are more than notebooks, where Power Point means more than handwritten overheads, and e-textbooks do more than simply replace hard copy textbooks. Often teachers are afraid technology may be broken, so restrictions are placed on students' usage even though educators acknowledge that young children need to explore and investigate in order to learn. In a study of early childhood classrooms where students lacked freedom to explore with iPads and laptops, O'Mara and Laidlaw (2011) noted the problem for teachers was not the technologies but the methods being used to implement them. Instead of using technologies to change approaches to the curriculum, teachers continued the regular drill and skill programs.

While media stories in Logan, Utah; Vancouver, British Columbia; and Knoxville, Tennessee touted school boards had funded new technologies for elementary classrooms, curricula were left unchanged. Teachers continued to drill skills using iPad, iPods, Smartboards, apps, and laptops to supplement material (Kirk, 2011; Little, 2011; Steffenhagan, 2011). Additionally, a new elearning requirement was established by the Idaho Board of Education which required high school students to take two credits of online coursework to graduate. Idaho's school reform initiative shifted funds from teacher and administrator salaries to technology improvements and a new focus on online learning (American School and University, 2011; Henig, \& Reville, 2011; Russell, 2011); however, teachers and parents responded negatively. The Idaho law as it pertained to technology use was overturned by voters in November 2012 (Robinson, 2012).

Change is sometimes slow and, oftentimes, change is slowest in education. Integration of technology into instruction happens when the teacher is comfortable and competent in doing so, provided that the technology resources are available to the teacher. Teachers will only become competent and confident when technology instruction is both provided and modeled for them in their own educations and when they are expected to use it in their teacher education program methods courses. If pre-service teachers graduate with full competence in the use of technology and familiarity in how to integrate it into education, the use of technology in public school classrooms 
will increase. If university classrooms are still relying on blackboards and chalk as the primary mode of instruction in teacher education, can we expect our graduates to do more?

\section{Technology and Teacher Education}

Teacher educators have long recognized that pre-service teachers emerge as competent practitioners as they go through stages of understanding of teaching and learning. Initially, pre-service teachers focus upon themselves and how much their students like them. Slowly they change their focus to organizing content and, ultimately, they begin to focus on student learning (Borich, 2000; Fuller, 1969; McCormack et al., 2006; Rhine \& Bryant, 2007). As pre-service teachers consider student-learning outcomes, they must develop reflective practice skills to see beyond the moment of classroom instruction and to plan for the ultimate achievement of larger goals for their students. As Rhine and Bryant (2007) stated:

Teacher education programs typically strive for pre-service and in-service teachers to see beyond the day-to-day requirements of teaching and to develop an ability to think intuitively, critically, and reflectively about the social, emotional, and intellectual elements of schools and classrooms. (p. 345)

The goal for teacher educators then is to shift the focus from reflecting on themselves to reflecting on the learning processes involved for themselves and their students. One way to help preservice teachers see beyond themselves and to begin focusing on their students may be through the integration of opportunities that technology provides. Teacher educators should provide opportunities for pre-service teachers to see technology integration, to observe mentors implementing appropriate technology practices, to become designers rather than users of technology, and to "think outside the box" (Koehler \& Mishra, 2005; Wilson, 2003; Wright \& Wilson, 2005). Such experiences will give pre-service teachers confidence to apply technology methods in their own classrooms. As a result they will investigate new ways to use technology to solve problems to "accommodate student needs, promote student learning, and better prepare students for the digital society" (Zhao, 2007, p.312).

According to Crocco and Cramer (2005), what is lacking in teacher education programs, with respect to technology use, is using technology as added value for presenting content to pre-service teachers. True technology integration is more than using a Power Point as an overhead projector or a Smartboard as a Power Point. Using technology in this way does not prepare pre-service teachers to use technology in any better way themselves once they enter a classroom. In a fouryear study of teacher candidates experiencing technology, Dawson (2006) found that "technology use did not bring about fundamental changes in instruction but instead either replaced, improved, or extended traditional instruction" (p.285).

Finally, Hooper and Rieber (1999) identified the following five stages for teacher use of technology: 1) familiarization, 2) utilization, 3) integration, 4) reorientation, and 5) evolution, noting that teachers typically do not progress past the utilization stage. For teachers to implement seamless technology instruction, teacher educators must examine ways to encourage the use of technology in instruction for pre-service teachers and to model this use for their pre-service teachers. In this way, teacher educators can help our nation's teachers move beyond familiarity and utilization into full integration of technology into our classrooms so that we can offer our $21^{\text {st }}$ century students the full power of modern technologies. This study looked at the way e-learning could be utilized within teacher education to address some of the issues discussed in the literature.

\section{Benefits of E-learning Technology in Higher Education}

E-learning has been defined by researchers in various ways. According to Sims (2008), e-learning opens new ways of learning and these new models change the essence of teaching and the dynam- 
ics of learning. He defines e-learning as, "forms of technology-enhanced learning that are efficient, effective, and engaging" (p.154). E-learning, as explained by Safran, Helic and Gutl, (2007), supports communities of practice where learners interact and learn together. Interaction typically occurs through discussion, commenting, collaborative writing, or working together on projects. In a study of secondary education teachers and college professors in Scotland, Davidson and Elliot (2007), defined e-learning as "any learning that is electronically mediated or facilitated by transactions software" (p.512). E-learning encourages students to be collaborative, contextual, and connected in their learning.

Monaco (2008) noted that "in education, a dichotomous perspective on technology exists: It is both praised and ignored in schools and in teacher education" (p.19). While Web 2.0 technology tools abound, too often teachers and professors in the field choose not to use the technological tools in their classrooms.

Numerous research studies confirm that pre-service teachers gain new insights into planning and organization, pedagogical strategies, delivery, content knowledge, and classroom management by analyzing and reflecting on video during their field experience (Alger \& Kopcha, 2009; Downey, 2008; Shepherd \& Hannafin, 2008; Snoeyink, 2010; Yeh, 2007). According to Rosaen, Lundeberg, Terpstra, Cooper, Fu, and Niu (2010), video based reflection helps with more specific comments about pre-service teachers' practice and shifts the focus from management to content and instruction. They also found that pre-service teachers analyzed and reflected on lesson strengths/weaknesses and gained a clearer vision of the role of the teacher in the classroom. Finally, in a study conducted by Snoeyink (2010), eight elementary and secondary pre-service teachers indicated a strong belief in the effectiveness of video self-analysis. The pre-service teachers saw themselves from the students' perspective, reduced their annoying mannerisms, and improved their management skills.

Students today are comfortable with technology as part of their daily lives. The North Carolina Center for the Advancement of Teaching (2009) found that technology engages students and advances their learning. Additionally, the International Society for Technology in Education (2008) noted that e-learning engages students, improves learning, enriches professional practice, and provides positive role models in teacher education. However, although the bulk of the literature describes positive benefits and outcomes associated with e-learning, some studies have found contradictory results.

\section{Mixed Messages Regarding E-learning}

In contrast to some of the studies describing the positive outcomes of e-learning, Capobianco (2007) studied 2,000 undergraduate teacher education students. He noted that integration of instructional technology to facilitate pre-service science teachers' learning was influenced more by the professor's philosophy than by the technology. In addition, Rhine and Bryant (2007) discovered issues related to the implementation of e-learning. In a three year study of MAT (Masters of Teaching) students, the students uploaded video clips to Blackboard, wrote a description of their lesson, and posted questions for their peers. Common topics emerged in the discussion but there were many negative issues in executing the technology tools. Initially, pre-service teachers did not have access to necessary technology tools in their classrooms. There was also a wide range of technical skills among the pre-service teachers and many students had significant anxiety implementing the technology.

\section{Summary}

Technology integration in the P-16 classroom is not keeping up with the use of technology in the real world. More effective use of technology in education with real purposes for learning out- 
comes needs to be established in our nation's classrooms and lecture halls. Technology is embedded in our daily lives. Our current college students have grown up using technology and are very comfortable using it in all aspects of their lives other than in the classroom, largely because it is still unfamiliar to them in this setting. This needs to change. Only when teachers and professors model the use of technology and implement it in their own classrooms will our future teachers feel comfortable in doing so themselves.

Although there are arguments on either side, overall, the literature supports the notion that elearning in higher education enhances teaching and learning experiences. E-learning, according to Christie and Ferdos (2004), is becoming increasingly important in higher education as a means of delivering teaching and learning. This study sought to investigate the use of e-learning in helping pre-service teachers connect their academic preparation with their practicum experience by allowing them to reflect upon their teaching experiences through the use of video sharing.

\section{Methods}

\section{Setting and Participants}

This study was conducted at a large public research university in the southeastern United States. Participants included 27 pre-service teachers (100\% female) in the field of elementary education enrolled in a beginning methods course. The average participant involved in this research was 20 years old ( $96 \%$ of students were 18 to 22 years of age) with some teaching experience. Ninety-six percent of the students had experience working with children in a classroom setting or in a tutoring situation, not including babysitting. Other participants included two university professors, five public school classroom teachers, and 100 public elementary school students enrolled in second grade at a local elementary school.

The course in which these pre-service teachers were enrolled is known as the "Link" on campus. It is a combined general methods course and language arts methods course with a supervised practicum. One professor is assigned to the general methods content of the course, another is responsible for the language arts content, and both are responsible for the supervision of the practicum experience at the local elementary school. The combined course is a nine credit-hour course that meets across two days a week from 8:00 a.m.-12:30 p.m.

\section{Procedures}

Participants were required to complete a teaching experience at a local elementary school by teaching three lessons that they designed and prepared themselves. The pre-service teachers spent considerable time across the semester immersed in their public school classroom experience. Each pre-service teacher spent 45 hours during the semester in the public school classroom either teaching their actual lessons, observing the classroom teacher, tutoring or mentoring individual children, and/or assisting the teacher with classroom needs.

The pre-service teachers received feedback about their teaching from the professors of the course, the classroom teacher to whom they were assigned for their practicum, and their classmates. The classroom teachers and the professors completed a teaching observation form for each pre-service teacher each time they taught. These observation forms were analyzed for growth in teaching skills throughout the semester. Pre-service teachers also completed teaching reflections after each of their individual teaching experiences.

In addition to reflecting on their own teaching, pre-service teachers were also required to view and reflect upon each other's teaching. This assignment was accomplished by using flip cameras to videotape each pre-service teacher's lesson. These videos were posted on a course website open only to the pre-service teachers enrolled in the course and their professors. Each pre-service 
teacher was required to view and then to reflect and respond to their classmates' teaching. Professors analyzed the videos and responded with feedback. Students reviewed videos and revised future lessons based on feedback from professors and peers. Students' used a Video Response Log that included the following questions to guide peer feedback:

1. What I saw (Describe the lesson you viewed). Be specific (at least 3-4 sentences).

2. What I liked. Be specific (at least 3-4 sentences).

3. Suggestions for enhancing the lesson. Provide at least 2 suggestions.

Figure 1 depicts the actual design of the project and shows the process used for the video reflection cycle.

\begin{tabular}{|c|c|c|c|c|c|c|c|c|c|c|c|c|}
\hline $\begin{array}{c}\text { Language } \\
\text { Arts Class } \\
3 \text { credit. } \\
\text { hours }\end{array}$ & $\Rightarrow$ & $\begin{array}{c}\text { Curriculum } \\
\text { Class } \\
3 \text { credit } \\
\text { hours }\end{array}$ & 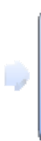 & $\begin{array}{l}\text { Practicum } \\
\text { Class } \\
1 \text { credit hour }\end{array}$ & $\Rightarrow$ & $\begin{array}{l}\text { Instructor F2F } \\
\text { Observation } \\
\text { Feedback }\end{array}$ & $\nabla$ & $\begin{array}{l}\text { Student } \\
\text { Video } \\
\text { Reflection }\end{array}$ & $\Rightarrow$ & $\begin{array}{l}\text { Instructor } \\
\text { Video } \\
\text { Feedback }\end{array}$ & 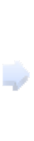 & $\begin{array}{c}\text { Peer } \\
\text { Video } \\
\text { Feedback }\end{array}$ \\
\hline
\end{tabular}

Figure 1: Project Design

Pre-service teachers received technology-specific training prior to their practicum experience. A university technology specialist spent one 40-minute class period with the pre-service teachers and explained in detail how to download video clips to their computers and then save on a CD. The process from beginning to end included: 1) Save the video from the flip camera to the computer, 2) share the video online, 3) burn the video to a disc, 4) submit the disc to your professor, 5) professor submits disc to the technology specialist, and 6) technology specialist uploads to course website. The process was time intensive, taking students approximately 30 to 60 minutes to complete steps one through five.

Pre-service teachers were grouped in triads for their teaching experiences. One member of the triad videotaped the lesson using a flip camera while a second triad member assisted the preservice teacher. After videotaping the lesson, downloading to the computer and saving to a CD, the pre-service teacher submitted the CD to the technology facilitator who then uploaded the video to the course website. Each day, the technology specialist uploaded multiple student video files to the course website. Pre-service teachers could then view their classmates' teaching episodes and share feedback on lessons.

Upon completion of the practicum experience, participants completed a post-test survey to determine perceived benefits of their participation in videotape reflection in practicum settings. The survey, student reflections, and instructor reflections identified challenges and successes the university instructors and pre-service teachers experienced in using and analyzing video in their teacher education methods coursework.

\section{Data Collection and Analysis}

Data were collected over a five-month period. Data sources included: a) videotapes, b) student reflections, c) cooperating teacher feedback, d) university instructor evaluations, e) surveys, and f) peer feedback. Responses were analyzed using a combination of content analysis (Silverman, 1999) and the constant-comparative method (Glaser \& Straus, 1967) to determine patterns or themes in the data.

Influenced by the code card method suggested by Fonteyn, Vettese, Lancaster, and Bauer-Wu (2008), the researchers created a card for each category with a description and inclusion criteria. First, responses from the video response logs were color coded into a notebook by successes and challenges. Each researcher read the video feedback and coded the responses into categories. Researchers ensured that the research findings possessed a measure of authenticity by being reflex- 
ive, respecting each other's perspectives and including original quotations and clarification of statements from the data.

A Likert scale survey of perceived benefits of the experience was administered to the pre-service teachers at the conclusion of the semester (see Appendix). Pre-service teachers completed the survey online via their Blackboard course website.

\section{Findings}

Findings from this study indicate mixed results regarding the use of e-learning to prepare preservice teachers in learning to teach. Over half of the pre-service teachers $(56 \%)$ strongly agreed or agreed that e-learning had improved their teaching during their practicum experience. Sixtythree percent posited that feedback from peers and professors improved the delivery of their lessons and that viewing the video clips improved their teaching. When questioned about viewing classmates' video clips, $66 \%$ of respondents noted they learned more about teaching and lesson planning by viewing their peers' teaching and $44 \%$ trusted their peers' evaluation of their own video clips. Yet, $78 \%$ of the pre-service teachers preferred video sharing feedback from their professors and $82 \%$ felt they learned more about teaching by viewing their own video clips of teaching. The post-test survey results indicating these perceived benefits of participation in videotape reflections are indicated in Table 1.

Table 1. Pre-Service Teachers' Opinion Survey Results

\begin{tabular}{|c|c|c|c|c|}
\hline E-learning for teaching and learning & $\begin{array}{l}\text { SA } \\
\text { (Strongly } \\
\text { Agree) }\end{array}$ & $\begin{array}{l}\text { A } \\
\text { (Agree) }\end{array}$ & $\begin{array}{l}\mathrm{D} \\
\text { (Disagree) }\end{array}$ & $\begin{array}{l}\text { SD } \\
\text { (Strongly } \\
\text { Disagree) }\end{array}$ \\
\hline \multicolumn{5}{|l|}{ E-learning improves teaching \& learning } \\
\hline $\begin{array}{l}\text { E-learning has improved my teaching during my } \\
\text { practicum experience. }\end{array}$ & $15 \%$ & $41 \%$ & $7 \%$ & $11 \%$ \\
\hline $\begin{array}{l}\text { Videosharing feedback has improved the delivery } \\
\text { of my lessons. }\end{array}$ & $19 \%$ & $44 \%$ & $22 \%$ & $4 \%$ \\
\hline I improved my teaching by viewing the video clips. & $11 \%$ & $52 \%$ & $22 \%$ & $11 \%$ \\
\hline $\begin{array}{l}\text { I learn more about my students when viewing the } \\
\text { video clips. }\end{array}$ & $26 \%$ & $37 \%$ & $11 \%$ & $15 \%$ \\
\hline $\begin{array}{l}\text { I have a better understanding of how to teach from } \\
\text { viewing the video clips. }\end{array}$ & $15 \%$ & $33 \%$ & $26 \%$ & $15 \%$ \\
\hline \multicolumn{5}{|l|}{ Peerfeedback } \\
\hline $\begin{array}{l}\text { Videosharing feedback from my peers helps me } \\
\text { prepare better lesson plans. }\end{array}$ & $7 \%$ & $52 \%$ & $22 \%$ & $11 \%$ \\
\hline $\begin{array}{l}\text { Videosharing has enabled classmates to learn a lot } \\
\text { from one another. }\end{array}$ & $11 \%$ & $41 \%$ & $15 \%$ & $7 \%$ \\
\hline $\begin{array}{l}\text { I learn more about teaching by viewing my class- } \\
\text { mates' video clips. }\end{array}$ & $7 \%$ & $59 \%$ & $26 \%$ & $4 \%$ \\
\hline I learn more from viewing my own video clips. & $26 \%$ & $56 \%$ & $4 \%$ & $7 \%$ \\
\hline \multicolumn{5}{|l|}{ Preferences } \\
\hline I prefer videosharing feedback from my professor. & $26 \%$ & $52 \%$ & $11 \%$ & $11 \%$ \\
\hline I prefer videosharing feedback from my peers. & $7 \%$ & $37 \%$ & $30 \%$ & $11 \%$ \\
\hline I enjoy viewing video clips of my own teaching. & $11 \%$ & $48 \%$ & $19 \%$ & $22 \%$ \\
\hline
\end{tabular}


Although over half of the pre-service teachers (59\%) used video sharing feedback to improve their lesson plans and teaching during the practicum experience, they clearly preferred using video sharing in combination with traditional methods for reflecting on teaching and lesson planning rather than video sharing alone.

While $44 \%$ of respondents preferred using traditional methods for reflecting and improving teaching, 52\% preferred using both traditional methods and video sharing techniques such as viewing video clips of themselves and their peers. Video sharing alone was preferred by only $4 \%$ of the pre-service teachers. See Figure 2.

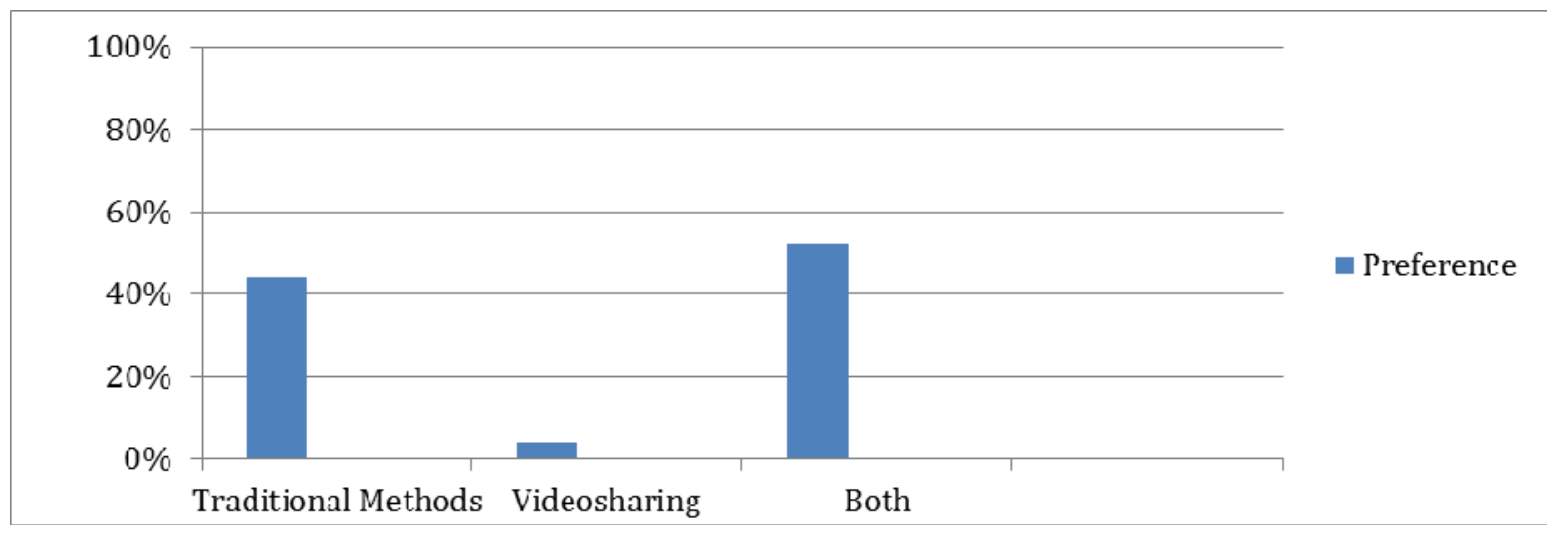

Figure 2. Teaching Feedback Preferences

Furthermore, $70 \%$ of participants stated they devoted a lot of effort to the video sharing experience and over half (52\%) said they did not enjoy video sharing and would not use this method to reflect and improve on their teaching in the future. While $63 \%$ percent noted that video sharing was difficult to implement using the Blackboard platform, over half $(56 \%)$ used the activities two to five times to improve their lesson plans and teaching during their practicum experience.

\section{Challenges and Successes}

Pre-service teachers viewed three teaching video clips online and commented on the lessons of their peers. Twenty-seven pre-service teachers posted 725 comments online with a mean of 6.8 video clips viewed, surpassing the course requirement by $44 \%$. Researchers used the Glasser and Straus (1967) constant-comparative method to determine themes in these comments. Pre-service teachers shared positive feedback as well as suggestions for improvement. Positive comments applauded pre-service teachers' efforts in using language arts strategies (34\%), hands-on activities/student engagement (19\%), visuals (15\%), dispositions (12\%) and classroom management $(11 \%)$. Suggestions for improvement were noted in regard to classroom management $(26 \%)$, planning (23\%), and time management (13\%). See Table 2.

Through content analysis of the positive and negative video feedback, the researchers identified emergent themes and were able to classify these messages into categories. See Table 3 and Table 4.

Participants made salient video sharing comments related to both positive feedback and suggestions of language arts strategies, student engagement, visuals, and dispositions. The pre-service teachers made suggestions to their peers for improvement in the areas of classroom management, planning, and time management. Time management is often difficult for novice teachers. As preservice teachers viewed their peers' teaching, they commented on ways to maximize time management in teaching. 
Table 2. Video Clip Comments

\begin{tabular}{|l|c|c|}
\hline \multicolumn{1}{|c|}{ Video Sharing Comment Categories } & $\begin{array}{c}\text { Student Suc- } \\
\text { cesses }\end{array}$ & $\begin{array}{c}\text { Student Chal- } \\
\text { lenges }\end{array}$ \\
\hline Instructional Strategies & $34 \%$ & $15 \%$ \\
Language arts/choral reading & $21 \%$ & $0 \%$ \\
Children's literature & $6 \%$ & $0 \%$ \\
Thinking maps & $3 \%$ & $0 \%$ \\
Explanations & $4 \%$ & $0 \%$ \\
Questioning & $0 \%$ & $8 \%$ \\
Probing & $0 \%$ & $1 \%$ \\
\hline Hands-on Activities/Student Engagement & $19 \%$ & $7 \%$ \\
\hline Visuals & $15 \%$ & $7 \%$ \\
\hline Dispositions & $12 \%$ & $9 \%$ \\
\hline Classroom Management & $11 \%$ & $26 \%$ \\
\hline Planning & $4 \%$ & $23 \%$ \\
\hline Time Management & $0 \%$ & $13 \%$ \\
\hline Other & $4 \%$ & $1 \%$ \\
\hline
\end{tabular}

Table 3. Themes in Video Response Feedback Noting Successful Teaching Practices

\begin{tabular}{|c|c|}
\hline Themes & Examples \\
\hline \multirow[t]{4}{*}{$\begin{array}{l}\text { Language Arts } \\
\text { Strategies }\end{array}$} & $\begin{array}{l}\text { "She allowed the students to interact with the text through her questions. } \\
\text { The questions made the students relate to the text and think about what was } \\
\text { being read." }\end{array}$ \\
\hline & "great job of asking the students questions while reading the book" \\
\hline & $\begin{array}{l}\text { "asked open-ended questions that required students to give her an answer } \\
\text { not just a yes or no. She asked for their opinion and also for how they } \\
\text { know" }\end{array}$ \\
\hline & "jigsaw, think-pair-share, KWL chart, Venn diagram, circle map.." \\
\hline \multirow[t]{3}{*}{$\begin{array}{l}\text { Student Engage- } \\
\text { ment }\end{array}$} & $\begin{array}{l}\text { "With every part of the lesson there was a hands on activity constantly } \\
\text { keeping the students engaged." }\end{array}$ \\
\hline & $\begin{array}{l}\text { "....demonstration with the jar and the bag. I thought this was a great way } \\
\text { to show the students what air pressure was. I also really liked the barome- } \\
\text { ter making activity because, for whatever reason, kids (at least in my ex- } \\
\text { perience) always like to build the instrument that you're measuring weather } \\
\text { with. They find this interesting. They were engaged with these two activi- } \\
\text { ties" }\end{array}$ \\
\hline & $\begin{array}{l}\text { "to write their answers to think/pair/share on the board, and I believe this } \\
\text { makes the activity a very engaging experience" }\end{array}$ \\
\hline
\end{tabular}




\begin{tabular}{|l|l|}
\hline Themes & Examples \\
\hline Visuals & $\begin{array}{l}\text { "The diagram of the water cycle was very simple and clear and helped ex- } \\
\text { plain 'runoff" to the students." }\end{array}$ \\
\hline & "She used pictures of tornadoes and hurricanes to enhance her lesson." \\
& $\begin{array}{l}\text { "Her visuals were great! The rain stick added a lot of fun to the book she } \\
\text { read." }\end{array}$ \\
\hline $\begin{array}{l}\text { "different students chances to read from her visuals and to have a part in } \\
\text { the lesson. That is a great way to get them engaged. I also liked the pictures } \\
\text { she showed them of sand dunes and Jockey's Ridge" }\end{array}$ & $\begin{array}{l}\text { "You were encouraging, positive, very enthusiastic, patient } \\
\text { and caring." }\end{array}$ \\
\hline $\begin{array}{l}\text { "She looked so comfortable with the students. She seemed calm and col- } \\
\text { lected throughout the whole lesson." }\end{array}$ & $\begin{array}{l}\text { "how she interacted with the students and spoke to them. She made sure } \\
\text { she was speaking in a way that was easy for them to understand" }\end{array}$ \\
\hline "warm and friendly manner" \\
$\begin{array}{l}\text { "was very positive and assertive when responding to the students and } \\
\text { showed a lot of enthusiasm throughout her entire lesson!" }\end{array}$ \\
\hline
\end{tabular}

Table 4. Themes in Video Response Feedback Noting Suggestions for Improving Teaching Practices

\begin{tabular}{|l|l|}
\hline Themes & Examples \\
\hline $\begin{array}{l}\text { Classroom Man- } \\
\text { agement }\end{array}$ & "Go over your classroom management plan before you start teaching." \\
\hline & "It is important to give instruction before any materials are passed out." \\
\hline & "It is very important to give praise without tangible rewards being given," \\
\hline & "Reinforce good behavior instead of calling out only bad behavior. When you \\
do this, they will be more likely to respond to a positive comment."
\end{tabular}




\begin{tabular}{|l|l|}
\hline Time Manage- \\
ment & $\begin{array}{l}\text { "have all your items for building the wind vane out already so it doesn't take } \\
\text { as long to get ready for the project" } \\
\text { couple of kids looked restless." }\end{array}$ \\
\hline & $\begin{array}{l}\text { "Give a specific time limit so students know how much time they have to do } \\
\text { something." }\end{array}$ \\
\hline $\begin{array}{l}\text { "There were some long breaks in the lesson. Keep the lesson moving at a } \\
\text { brisk pace." }\end{array}$ \\
$\begin{array}{l}\text { "book seemed to go longer than students stayed engaged and I would sug- } \\
\text { gests selecting certain key pages in the book in order to maintain time and } \\
\text { student attention" }\end{array}$ \\
\hline $\begin{array}{l}\text { "I would give them a specific time limit so they know how much time they } \\
\text { have to do something" }\end{array}$ \\
\hline
\end{tabular}

\section{Discussion and Practical Implications}

According to the results of this research, the use of e-learning engaged participants in reflection and feedback for mentoring and coaching of post teaching video discussions. This engagement enhanced pre-service teachers' practice in real life classroom settings. A few participants indicated prior knowledge of teaching best practices, but overall, participants cited the e-learning experiences as complementary best practice for beginning teacher educators. The improved planning and implementation skills reflect the findings of Alger and Kopcha (2009), Downey (2008), Kay, Knaack, and Petrarca (2009), Shepherd and Hannafin (2008), Snoeyink (2010), and Yeh (2007). Participants reported improved lesson planning, improved lesson implementation, visual interpretations of best practices, modeling, and peer and university instructor feedback as successes of the e-learning project.

Challenges of the project included participants' frustrations of being overworked and overwhelmed with the technical problems associated with downloading their video clips. The cumbersome video download process echoes the experience of other teachers (Bauer \& Kenton, 2005; Hofer \& Swan, 2006). Respondents reported they encountered difficulties transferring video from the flip cameras to their computers, then uploading to a DVD, and finally sharing with the technologist who in turn posted the videos online. The process was lengthy and cumbersome. Many students spent from 30 minutes to an hour after class waiting for the video to download from the flip camera to the computer. MAC and PC computer programs responded differently to the method of video transfer, which added to the student frustrations. However, once the students had access to their videos online, they were pleased with the capability of viewing and reflecting on their own and their classmates' teaching episodes.

Participants judged the e-learning project as a very positive aspect of their teacher training. Authentic settings recorded and posted online enabled participants to evaluate, redesign, and improve teaching practice. Instructors and peers provided support through online discussion boards. Online feedback and reflections provided support for beginning teacher education candidates in that participants were made well aware of university instructors' expectations.

As noted by Wang (2009), applying blended learning to teacher education maintains and improves the quality of teaching preparation, and the results of this research support the benefits of applying e-learning in teacher education at the program level. However, these findings also indicate students did not favor e-learning as a method for learning to teach. Pre-service teachers 
found e-learning methods beneficial, yet cumbersome and difficult, and they preferred both traditional methods and video sharing together as a means of teaching reflection.

While the video sharing findings of this project agreed with the literature in reaping rewards for students in planning and implementing lessons, students preferred video sharing feedback from professors only when paired with traditional methods of feedback. The technology process of using flip cameras, downloading videos to the computer, and uploading to a CD limited this study. The university technology capabilities are up-to-date in many areas, but using video sharing is in early stages of development and was not user-friendly at the time of this study. Furthermore, similar to the study by Rhine and Bryant (2007), there were a wide range of technical skills among the pre-service teachers, and according to Saade and Kira (2009) many students had significant anxiety implementing the technology.

\section{Conclusions}

The undergraduate students' e-learning experiences in this study are similar to those reported in the research literature, thus extending the literature in this area. However, this research adds to the current literature by suggesting e-learning as a model of support to add rigor and relevance to teacher education methods instruction. As noted by Bates (2005), the choice of technology should be driven by the needs of the learners and the context in which the learners, in this study our pre-service teachers, are working.

As instructors of the e-learning project, lessons were learned from this initial implementation that will guide future implementations. Practice and competence with the full implementation of video clip uploading to the website prior to classroom use by the students is a necessity. Suggestions for future implementations of this project include: 1) secure online technology support for students throughout the practicum experience rather than relying only on one initial training experience, and 2) plan several practice sessions of the process from beginning to end before students actually implement their lessons at the practicum. Students will gain confidence and competence in the process thereby entering the project with full knowledge of how to navigate the technology of the e-learning activity. The benefits of e-learning were recognized by the participants, but were somewhat overshadowed by the technological difficulties experienced. Relieving those difficulties may allow the benefits of the actual e-learning experience to be more fully realized.

As university teacher education programs strive to bridge the gap between academic preparation and practice, as well as to model effective integration of technology in the classroom setting, this e-learning experience provided a model of renewed support for university instruction in designing and implementing best teaching practices. Future research is needed to deepen learning experiences for pre-service teachers. As teacher educators, we must continue to ask ourselves, "Did our students transfer learning outcomes from research pedagogy to practice? Could we do more to add depth and breadth and how? Are pre-service teachers gaining the ability to think intuitively and critically through the use of e-learning?"

\section{Acknowledgement}

This article is a substantial revision of an earlier paper entitled "E-Learning: Using Technology to Guide Teaching Practice." We gratefully acknowledge the support of Professor John Beachboard, Idaho State University, for his valuable comments and guidance that added depth to our study. 


\section{References}

Albion, P. (2008). Web 2.0 in teacher education: Two imperatives for action. Computers in the Schools, 25(3/4), 181-198.

Alger, C., \& Kopcha, T.J. (2009). eSupervision: A technology framework for $21^{\text {st }}$ century field experience in teacher education. Issues in Teacher Education, 18(2), 31-46.

American School and University. (2011). Online courses required in Idaho. Retrieved December 20, 2011 from http://asumag.com/maintenancebusiness/online-courses-required-idaho

Bauer, J., \& Kenton, J. (2005). Toward technology integration in the schools: Why it isn't happening. Journal of Technology and Teacher Education, 13(4), 519-546.

Bates, A. W. (2005). Technology, e-learning and distance education. New York: Taylor \& Francis.

Borich, G. D. (2000). Effective teaching methods. New Jersey: Merrill.

Capobianco, B. (2007). A self-study of the role of technology in promoting reflection and inquiry-based science teaching. Journal of Science Teacher Education, 18(2), 271-295.

Christie, M. F., \& Ferdos, F. (2004). The mutual impact of educational and Information technologies: Building a pedagogy of e-learning. Journal of Information Technology Impact, 4(1), 15-26.

Crocco, M., \& Cramer, J. (2005). Technology use, women, and global studies in social studies teacher education. Contemporary Issues in Technology and Teacher Education [Online serial], 5(1). Retrieved May 8, 2012 from http://www.citejournal.org/vol5/iss1/socialstudies/article1.cfm

Cuban, L. (2001). Oversold \& underused: Computers in the classroom. Cambridge, MA: Harvard University Press.

Davidson, J. K., \& Elliot, D. L. (2007). A comparison of e-learning in Scotland's colleges and secondary schools: The case of national qualifications in 'core skills'. Journal of Computer Assisted Learning, $23,511-522$.

Dawson, K. (2006). Teacher inquiry: A vehicle to merge prospective teachers' experience and reflection during curriculum-based, technology-enhanced field experiences. Journal of Research on Technology in Education, 38(3), 265-292.

Downey, J. (2008). "It's not as easy as it looks": Preservice teachers' insights about teaching emerging from an innovate assignment in educational psychology. Teaching Educational Psychology, 3(1), 1-13.

Duquette, C. (1993). A school-based teacher education program: perceptions and attitudes. Alberta Journal of Educational Research, 39(4), 419-432.

Fang, Z. (1996). A review of research on teacher beliefs and practices. Educational Research, 38(1), 47-65.

Fonteyn, M. E., Vettese, M., Lancaster, D. R., \& Bauer-Wu, S. (2008). Developing a codebook to guide content analysis of expressive writing transcripts. Applied Nursing Research, 21, 165-168.

Fuller, F. (1969). Concerns of teachers: A developmental conceptualization. America Educational Research Journal, 2(6), 207-226.

Glaser, B. G., \& Straus, A. L. (1967). The discovery of grounded theory. Chicago: Aldine

Henig, J., \& Reville, S. (2011). Idaho sets the stage for new e-learning requirement. Education Week, $31(12), 8$.

Hofer, M., \& Swan, K. (2006). Standards, firewalls, and general classroom mayhem: Implementing student-centered technology projects in the elementary classroom. Contemporary Issues in Technology and Teacher Education, 7(2), 42-58.

Hooper, S., \& Rieber, L.P. (1999). Teaching, instruction, and technology. In A. C. Ornstein \& L. S. BeharHorenstein (Eds.), Contemporary issues in curriculum (pp.252-264). Boston: Allyn and Bacon. 
Hsu, S. (2010). The relationship between teacher's technology integration ability and usage. Journal of Educational Computing Research, 43(3), 309-325.

International Society for Technology in Education. (2008). ISTE's educational technology standards for teachers. Retrieved January 8, 2012 from http://www.iste.org/Content/NavigationMenu/NETS/ForTeachers/2008Standards/NETS for Teachers 2008.htm

Kay, R., Knaack, L., \& Petrarca, D. (2009). Exploring teachers' perceptions of web-based learning tools. Interdisciplinary Journal of E-Learning and Learning Objects, 5, 27-50. Retrieved April 23, 2012 from www.ijello.org/Volume5/IJELLOv5p027-050Kay649.pdf

Kirk, A. (2011, January 10). Apple in the classroom: Students using iPods, iPads to improve reading, math. [Online newspaper article]. Retrieved November 20, 2011 from http://news.hjnews.com/news/education/article 937f4736-1c7b-11e0-94f2-001cc4c03286.html

Koehler, M., \& Mishra, P. (2005). Teachers learning technology by design. Journal of Computing in Teacher Education, 21(3), 94-102.

Koehler, M., \& Mishra, P. (2007). Introducing technological pedagogical knowledge. In The American Association of Colleges of Teacher Education (Ed), The handbook of technological pedagogical content knowledge for teaching and teacher educators. Mahwah, NJ: Lawrence Erlbaum.

Lai, G., \& Calandra, B. (2010). Examining the effects of computer-based scaffolds on novice teachers' reflective journal writing. Educational Technology Research \& Development, 58, 421-437.

Little, K. (2011, February 6). Web school to require students in grades 4-12 to have iPads for learning.[Online newspaper article]. Retrieved August 22, 2011, from http://www.knoxnews.com/news/2011/feb/06/turning-the-electronic-page/

McCoog, I. (2008). 21 st century teaching and learning. Retrieved February 19, 2012 from http://www.eric.ed.gov/ERICWebPortal/recordDetail?accno=ED502607

McCormack, A., Gore, J., \& Thomas, K. (2006). Early career teacher professional learning. Asia-Pacific Journal of Teacher Education, 34(1), 95-113.

Moersch, C. (2011). Turning up the H.E.A.T. on student learning: Assessing $21^{\text {st }}$ century skills in classrooms today. Educational Technology, 52(3), 42-46.

Monaco, M. (2008). Opening our eyes to the power of technology. Reading Today, 26(3), 19.

Moylan, W. (2008). Learning by project: Developing essential $21^{\text {st }}$ century skills using student team projects. International Journal of Learning, 15(9), 287-292.

North Carolina Center for the Advancement of Teaching. (2009). Technology engages students, advances learning. NCCAT Winter Newsletter, 22(1), 5.

O'Mara, J., \& Laidlaw, L. (2011). Living in the iworld: Two literacy researchers reflect on the changing texts and literacy practices of childhood. English Teaching: Practice and Critique, 10(4), 149-159.

Orey, M., McClendon, V. J., \& Branch, R. M. (Eds.). (2006). Educational media and technology yearbook. Englewood, CO: Libraries Unlimited.

Rhine, S., \& Bryant, J. (2007). Enhancing pre-service teachers' reflective practice with digital video-based dialogue. Reflective Practice, 8(3), 345-358.

Robinson, J. (2012, November 07). Idaho rejects teacher pay reforms, classrooom technology laws [Online newspaper article]. Retrieved from May 18, 2012 http://www.opb.org/news/article/n3-idaho-rejectsteacher-pay-reforms-classroom-technology-laws/

Rosaen, C. L., Lundeberg, M., Terpstra, M., Cooper, M., Fu, J., \& Niu, R. (2010). Seeing through a different lens: What do interns learn when they make video cases of their own teaching? Teacher Educator, $45,1-22$. 
Pre-Service Teachers Use E-learning Technologies

Ross, E. (2000). The praise and perils of e-learning. Theory and Research in Social Education, 28(4), 482492.

Russell, B. (2011). Idaho to require two online classes. Retrieved May 18, 2012 from http://www.spokesman.com/stories/2011/nov/04/idaho-to-require-two-online-classes/

Saade, R., \& Kira, D. (2009). Computer anxiety in e-learning: The effect of computer self-efficacy. Journal of Information Technology Education, 8, 177-191. Retrieved January 3, 2012, from www.jite.org/documents/Vol8/JITEv8p177-191Saade724.pdf

Safran, C., Helic, D., \& Gutl, C. (2007, September). E-learning practices and Web 2.0. Paper presented at the meeting of the International Conference on Interactive Computer Aided Learning, Villach, Austria.

Shepherd, E. E., \& Hannafin, M. J. (2008). Examining preservice teacher inquiry through video-based, formative assessment e-portfolios. Journal of Computing in Teacher Education, 25(1), 31-37.

Silverman, D. (1999). Interpreting qualitative data: Methods for analyzing talk, text, and interaction (2nd ed). London: Sage.

Sims, R. (2008). Rethinking (e)learning: A manifesto for connected generations. Distance Education, $39(92), 153-164$.

Snoeyink, R. (2010). Using video self-analysis to improve the "withitness" of student teachers. Journal of Digital Learning in Teacher Education, 23(3), 101-110.

Steffenhagan, J. (2011, January 13). No more pencils, no more books: This Vancouver School has embraced iPad, iPods, and apps. The Vancouver Sun. Retrieved June 9, 2012 from http://www.vancouversun.com/technology/Photos+more+pencils+more+books+Vancouver+school+e mbraces + iPads/4106245/story.html

Swain, C. (2006). Preservice teachers' self-assessment using technology: Determining what is worthwhile and looking for changes in daily teaching and learning practices. Journal of Technology and Teacher Education. 14(1), 29-59.

Vockley, M. (2007). Maximizing the impact: The pivotal role of technology in a $21^{\text {st }}$ century education system. Retrieved October 2, 2011 from http://info.watertown.k12.ma.us/academics/documents/P21document-2007.pdf

Walker, E., Redmond, J., \& Giles, M. (2010). Multivariate analysis of attitudes of elementary education teachers towards the environment, computers and E-learning. International Journal of Business Studies, 18(1), 55-72. Retrieved October 2, 2011 from http://search.proquest.com/docview/821544280?accountid=10639

Wang, Y. (2009). A case study of an accelerated blended teacher education program. Dissertation Abstracts International, Retrieved October 2, 2011, from http://www.scribd.com/doc/30902662/Elearning-on-Teacher-Education (UMI No. 3358950).

Wilson, E. (2003). Preservice secondary social studies teachers and technology integration: What do they think and do in their field experiences? Journal of Computing in Teacher Education, 20(1), 29-39.

Wright, V., \& Wilson, E. (Winter 2005-2006). From preservice to inservice teaching: A study of technology integration. Journal of Computing in Teacher Education, 22(2), 49-55.

Yeh, Y. C. (2007). Integrating e-learning into the direct instruction model to enhance the effectiveness of critical-thinking instruction. Instructional Science, 37, 185-203.

Zhao, Y. (2007). Social studies teachers' perspectives of technology integration. Journal of Technology and Teacher Education, 15(3), 311-333. 


\section{Appendix}

\section{E-learning Survey}

This survey is being used to determine how the use of E-learning affects the performance of teacher education candidates in practicum settings. The survey will also determine the struggles, challenges and successes students experience in using and analyzing video in teacher education methods coursework.

\section{Part one. Please tell us about yourself.}

1. Please indicate your gender.

Male

Female

2. What is your age?

$18-22$

$23-27$

28-32

$33-37$

$38+$

3. How many years of experience do you have working with children in a classroom setting or in a tutoring situation? Do not include babysitting.

0

less than 1

$1-2$

$2-3$

$3-4$

4. How many of your professors have instructed using some type of advanced technology (beyond power points and Blackboard) and/or require you to use it?

none

a few

about half

most

all

Part two. Please tell us about your use of E-learning.

5. Indicate your experience and/or comfort level in using each Web 2.0 tool listed below. Use the following scale for your ratings:

5 - Proficient/Very Comfortable

4 - Developing/Somewhat Comfortable

3 - Developing/Somewhat Uncomfortable 
2 - Limited/ Uncomfortable

1 - Have not tried, but would like to learn

0 - I don't know what this is.

\section{Experience/Comfort Level}

\section{$\begin{array}{llllll}5 & 4 & 3 & 2 & 1 & 0\end{array}$}

Blogs (Blogger, Blogmeister)

Wikis (Wikispaces, PBWiki)

Social Bookmarking (Delicious, Digg)

Social Networking (Facebook, MySpace)

Microblogging (Twitter)

Online presentations (VoiceThread, Google Docs)

Videosharing (Video Clips, YouTube, TeacherTube)

Photosharing(Flikr, Picasa)

Web tours (Trailfire)

Podcasting - downloading and using (news feeds, NPR, iTunes)

Podcasting - creating and publishing (GarageBand, Audacity)

6. Have you used any of these tools to prepare or teach a lesson? Check all that apply

blogs

wikis

social bookmarking

social networking

microblogging

online presentations

videosharing

photosharing

web tours

podcasting - downloading and listening

podcasting - creating and publishing

Other

7. If you haven't used any of the above or only a few, why have you not done more?

no internet access in schools

firewall

never occurred to me

I'm not comfortable with the technology 


\section{Part three. Please give us your opinion of the use of E-learning for teaching and learning.}

8. For each of the statements below, indicate your level of agreement. Use the following scale for your ratings.

SA - Strongly agree

A - Agree

D - Disagree

SD - Strongly disagree

$\mathrm{N}$ - No opinion or Not applicable

E-learning has improved my teaching during my practicum experience.

The videosharing feedback from my peers helps me prepare better lesson plans.

I learn more about teaching by viewing my classmates' video clips.

I learn more about teaching by viewing my own video clips of teaching.

I prefer videosharing feedback from my professor.

I prefer videosharing feedback from my peers.

Getting videosharing feedback from my peers and professors has helped me improve the delivery of my lessons.

I trust my peers evaluation of my teaching via video clips.

I enjoy viewing video clips of my own teaching.

I learn more about lesson planning by viewing the video clips of my peers' teaching.

I have improved my teaching by viewing the video clips.

I have access to the technology to participate fully in the videosharing activities.

Videosharing has been easy to implement via Blackboard.

Using videosharing has enabled the people in this class to learn a lot from one another.

I learn more about my students when viewing the video clips.

I have a better understanding of how to teach because of the information I gained from viewing the video clips.

I enjoy using videosharing.

In the future, I will use videosharing to reflect and improve on my teaching.

I devoted a lot of effort to the videosharing experience 


\section{Part four. Please reflect on your use of videosharing.}

9. How often did you use the videosharing feedback to improve your lesson plans and teaching during your practicum experience?

I did not use the feedback from the video clips.

Once

2 - 5 times

More than 5 times.

10. I prefer reflecting and improving my teaching using:

traditional methods

Videosharing techniques such as viewing video clips

Both

11. Explain your answer to question $\mathbf{1 0 .}$

Thank you for completing the survey.

\section{Biographies}

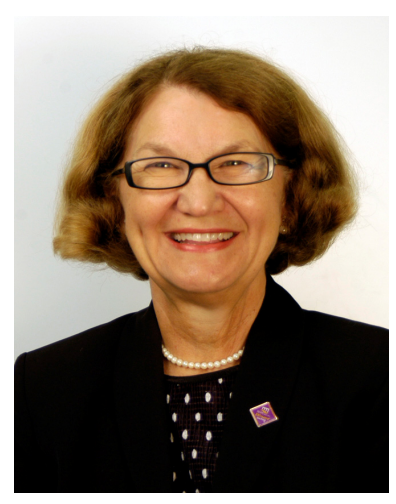

Dr. Judith J. Smith is an Assistant Professor in the College of Education, Department of Elementary Education and Middle Grades Education at East Carolina University, Greenville, N.C. Her research interests include language/literacy, educational technology $/ 21^{\text {st }}$ century literacies, and teacher-education. Dr. Smith has published articles in Insight: A Journal of Scholarly Teaching, The Delta Kappa Gamma Bulletin, Computers in the Schools, Current Issues in Education and Studying Teacher Education. She is a member of the Delta Kappa Gamma Society International, the Literacy Research Association, and the American Educational Research Association. She has presented nationally and internationally at AACTE, ELEARN, SITE, AERA, and LRA

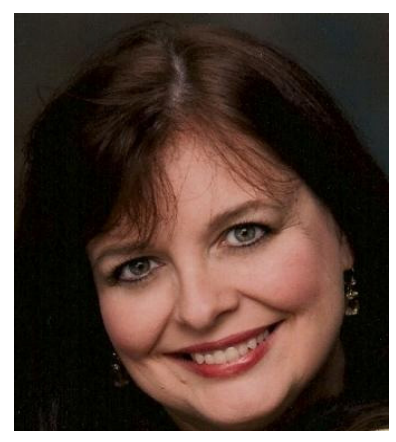

Dr. H. Carol Greene is an Associate Professor of Education in the Department of Elementary Education and Middle Grades Education at East Carolina University in Greenville, NC. She has a PhD in Educational Psychology from Virginia Tech. Her research interests include technology in teacher education and working with children and families from poverty. She has published more than 20 articles and has given over 40 presentations related to these topics. 